\title{
MENINGKATKAN KOMITMEN KARYAWAN MELALUI EMPLOYEE STOCK OWNERSHIP PROGRAM UNTUK MENINGKATKAN KESEJAHTERAAN KARYAWAN
}

\author{
Elizabeth Tiur Manurung \\ eliz@unpar.ac.id \\ Fakultas Ekonomi, Universitas Katolik Parahyangan.
}

diterima: 23/9/2018; direvisi: 10/10/2018; diterbitkan: 29/10/2018

\begin{abstract}
The purpose of this research is to ascertain the implementation of ESOP which has proven to increase employees' commitment and motivation that can be measured through company's profit proxy, and the increase in profit could increase employees 'welfare. This research used descriptive method that ensure each characteristic of the variables to obtain the validity of the data, hence it could be proven and improved to solve problems and create logical conclusion. PT Bandung has established stock fund through ESOP program, with the diversion partly of common stocks IDR 600 million on a par of 600.000 shares. The result of this research has proven a significant impact of implementation of ESOP, such as increasing in employee's commitment and motivation. The $257,7 \%$ increase in profit compare to last year indicates company values has improved, as a result from employee productivity increased and company welfare elevated besides ensuring company sustainability.
\end{abstract}

Keywords: share ownership; employee commitment; company profit; compensation; prosperity; welfare

\begin{abstract}
Abstrak
Tujuan penelitian ini adalah untuk mengetahui benarkah pelaksanaan ESOP di PT. Bandung meningkatkan komitmen dan motivasi karyawan, yang diukur melalui proksi Laba perusahaan, dan apakah kenaikan Laba, dapat mensejahterakan warga perusahaan. Metode penelitian yang digunakan adalah studi Deskriptif, yang memastikan karakteristik setiap variabel, untuk mendapatkan data yang valid sehingga dapat, dibuktikan, dan dikembangkan suatu pengetahuan untuk memecahkan masalah dan membuat kesimpulan yang logis. PT Bandung, membentuk badan pengelola dana saham untuk kepentingan karyawan yaitu program ESOP, dengan pengalihan sebagian saham biasa Rp. 600 juta setara dengan 600.000 lembar saham. Hasil penelitian membuktikan terdapat dampak yang besar atas implementasi ESOP, adanya peningkatan laba $257,7 \%$ dibandingkan tahun lalu, yang disebabkan adanya peningkatan komitmen dan motivasi karyawan, sehingga nilai perusahaan serta kompensasi meningkat, para karyawan meningkat kesejahteraannya, selain mendukung tercapainya keberlanjutan.
\end{abstract}

Kata Kunci: kepemilikan saham; komitmen karyawan; laba perusahaan; kompensasi; kesejahteraan 


\section{PENDAHULUAN}

Upaya yang sangat serius dapat dilihat dari Pemerintahan daerah Kota Bandung, untuk meningkatkan kualitas kerja warga Bandung, melalui program Walikota yaitu Program memberangkatkan 1.200 warga Bandung untuk memperoleh pelatihan kerja di Jepang. Hal ini ditujukan agar masyarakat Bandung dapat meningkat kualitas kerjanya dan kedisiplinan kerjanya. (www.portal.bandung.go.id/ posts/2017/05/16/X9D2). Walikota Bandung, Bapak Ridwan Kamil, mengharap kan bahwa melalui pelatihan ini, sedikit demi sedikit warga Bandung dapat meningkat kesejahteraannya, demikian halnya harapan Wakil Walikota Bandung, yaitu Pemerintah Daerah Kota Bandung akan berupaya mensejahterakan dan membahagiakan warga Kota Bandung. Memang, umumnya untuk meningkatkan kualitas Tenaga kerja di perusahaan dapat dilakukan melalui berbagai pelatihan, menempuh studi lanjutan serta menempuh berbagai sertifikasi sesuai kekhususan yang diambilnya.

Berdasarkan data Badan Pusat Statistik, 2016 seperti yang dikutip Enny Sri Hartati pada Harian Kompas (17.04.17: H. 15), bahwa baru sekitar 10\% tenaga kerja di Indonesia yang memiliki sertifikat keakhlian kerja dan/ ketrampilan kerja. Hal ini menyulitkan perusahaan untuk mencari tenaga kerja yang akhli di bidangnya serta kualitas tenaga kerja di berbagai bidang belumlah sesuai dengan yang diharapkan, bahkan kualitas sember daya manusia yang ada di berbagai perusahaan masih dianggap sebagai hambatan dalam meningkatkan kinerja perusahaan.

Kinerja suatu perusahaan salah satunya ditentukan oleh kualitas Sumber Daya Manusianya (SDM). Kecukupan jumlah dan kualitas SDM sangatlah penting bagi perusahaan karena SDM yang semakin produktif akan lebih bermanfaat bagi perusahaan karena semakin efisien. Efisiensi operasi perusahaan dapat dicapai melalui penerapan ESOP, seperti hasil penelitian Zhu et. al. (2013) pada perusahaan perangkat Telekomunikasi yang sedang berkibar sekarang ini, yaitu Huawei, yang menyimpulkan bahwa penerapan ESOP mendorong efisiensi dan pertumbuhan perusahaan seacara signifikan. Peningkatan efisiensi menghasilkan laba yang semakin meningkat sehingga kontribusi kepada para stake holders sebagai warga perusahaan akan semakin besar (Brigham, 2013). Pengembangan SDM adalah merupakan tanggung jawab perusahaan terutama dalam persaingan bisnis yang semakin tajam serta kondisi semakin langka dan terbatasnya karyawan yang memiliki skill yang dibutuhkan oleh perusahaan.

Meningkatkan kualitas SDM salah satunya dapat dilakukan melalui penerapan program ESOP, karena bila karyawan memiliki sebagian saham perusahaan maka rasa memiliki terhadap perusahaan menjadi lebih tinggi (Brigham: 2013). Hasil riset Susilawaty (2017; yang dikutip oleh Putra, 2018), menyatakan bahwa pelaksanaan ESOP di perusahaan ternyata berpengaruh positif dalam meningkatkan penjualannya. SDM lebih produktif karena mampu menghasilkan kerja yang lebih tinggi. Selanjutnya laba perusahaan akan meningkat dan kompensasi kepada stake holders' termasuk karyawan dan para pemegang saham menjadi lebih tinggi. Hasil penelitian Ripperger (2018) menyimpulkan bahwa para karyawan dalam perusahaan yang telah menerapkan ESOP menjadi lebih optimis karena kenaikan keuntungan yang signifikan akan mereka terima saat pensiun.

Di Indonesia sendiri, implementasi ESOP sebenarnya sudah dilakukan sejak sekitar Tahun 2000, sebagimana yang tercantum dalam Hasil riset Badan Pengawas Penanaman Modal (Bapepam, 2002 dikutip oleh Putra, 2018), namun disebutkan pula terdapat kendala bahwa belum ada aturan yang jelas tentang penyelenggaraan ESOP. Sampai Presiden Jokowi sendiri turut menyerukan pentingnya penyelenggaraan Program pemilikan saham oleh karyawan ini, pada saat pelaksanaan ESOP oleh PT. Sri Rejeki Isman yaitu perusahaan garmen, yang terjadi pada tahun 2015 (Putra, 2018).

Adanya kendala tentang belum jelasnya peraturan penyelenggaraan ESOP (Putra, 2018), bila dihubungkan dengan hasil penelitian (Tarigan et al, 2013) tentang aspek Yuridis kepemilikan saham bagi karyawan pada perseroan terbatas, aturan ini dikatakan masih terbatas seperti kesimpulan penelitiannya, yaitu (1) pengaturan mengenai kepemilikan saham bagi karyawan belum menyeluruh, (2) terdapat sarana program untuk membuat kepemilikan saham oleh karyawan, (3) kepemilikan saham oleh karyawan yang dimaksud adalah pada perseroan terbatas.

Uraian di atas menjadi latar belakang, mengapa topik ESOP ini diteliti, yaitu Bagaimana pelaksanaan program ESOP di PT. Bandung dapat meningkatkan komitmen karyawan, yang diukur melalui proksi Laba. Diharapkan dengan kenaikan Laba, perusahaan dapat lebih mensejahterakan warganya, selain mendukung pula tercapainya keberlanjutan operasi perusahaan.

Motivasi penelitian ini yaitu ingin memecahkan berbagai masalah, yang dirangkum dalam tiga poin tujuan penelitian sebagai berikut: (1) untuk mengetahui jenis program kepemilikan saham oleh Karyawan apa yang diterapkan di PT. Bandung; (2) Untuk mengetahui bagaimana implementasi program tersebut; (3) serta mengetahui bagaimanakah dampak program tersebut terhadap Laba perusahaan dan kesejahteraan warga perusahaan.

Program ESOP didefinisikan Brigham (2013) sebagai salah satu bentuk kompensasi yang diberikan kepada karyawan, untuk menghargai para eksekutif atas kinerja yang diberikannya kepada perusahaan secara jangka panjang. Sementara Herdinata (2012), mendefinisikannya sebagai program kepemilikan interest di perusahaan dalam bentuk kepemilikan 
saham perusahaan oleh karyawan, yang diharapkan meningkatkan rasa memiliki (sense of belonging) sehingga dapat mendukung peningkatan kinerja perusahaan.

Pada umumnya, ESOP diberikan kepada karyawan Eksekutif(Brigham, 2013), yang merupakan pemindahan sebagian saham dari share holders kepada karyawan dilakukan dalam periode yang panjang misalnya 15 tahun, karena saham akan diserahkan kepada karyawan pada saat pensiun agar saat pensiun terjadi penambahan kekayaan karyawan.

Hasil penelitian Brigham (2013) menunjukkan bahwa $90 \%$ karyawan yang melaksanakan optionnya untuk membeli saham ternyata segera menjual sahamnya kembali. Dengan kesimpulan penelitian bahwa program ini meningkatkan motivasi karyawan namun dalam periode jangka pendek. Inilah alasan mengapa perusahaan memberikan ESOP akhirnya hanya untuk para eksekutif sehingga dampaknya dapat diterima oleh perusahaan secara jangka panjang.

Hasil penelitian Brigham (2013), juga menunjukkan bahwa 9.000 perusahaan swasta dan 1.000 perusahaan pemerintah telah memiliki program ESOP. Umumnya saham yang dijual kepada karyawan adalah common stock, dan $25 \%$ perusahaan yang memiliki program ESOP merupakan perusahaan yang memiliki major interest.

ESOP diselenggarakan oleh perusahaan untuk mencapai beberapa tujuan, menurut BAPEPAM (2002, dalam Putra, 2018) dikatakan ada beberapa tujuan yang ingin dicapai misalnya: (1) memberikan penghargaan kepada semua pihak yang berkontribusi terhadap peningkatan kinerja perusahaan; (2) menciptakan keselarasan kepentingan antar principal dan agen; (3) meningkatkan motivasi dan komitmen karyawan, sehingga produktivitas perusahaan dapat meningkat; (4) sebagai sarana untuk meraih keberhasilan strategi bisnis perusahaan jangka panjang.

Untuk lebih jelasnya, tujuan diselenggarakannya ESOP dalam perusahaan diantaranya adalah: (1) untuk memberikan penghargaan (reward) kepada seluruh pegawai, direksi, dan pihak-pihak tertentu atas kontribusinya terhadap perusahaan sehingga kinerja perusahaan meningkat; (2) menciptakan keselarasan kepentingan serta misi dari pegawai dan pejabat eksekutif dengan kepentingan dan misi pemegang saham, sehingga tidak ada benturan kepentingan antara pemegang saham dan pihak-pihak yang menjalankan kegiatan operasi perusahaan; (3) meningkatkan motivasi dan komitmen karyawan terhadap perusahaan karena mereka juga merupakan pemilik perusahaan, sehingga diharapkan akan meningkatkan produktivitas dan kinerja perusahaan; (4) mempertahankan kinerja pegawai agar shareholders' value dapat meningkat; (5) sebagai implementasi strategi bisnis jangka panjang, dengan memberikan reward kepada karyawan berdasarkan kinerja yang dicapai karyawan (Brigham, 2013).
BAPEPAM (2002 dalam Putra, 2018), mengungkapkan berbagai hal yang dapat mengurangi keberhasilan ESOP yang diselenggarakan oleh perusahaan serta mempengaruhi karyawan sebagai peserta ESOP, antara lain: (1) kurangnya pengetahuan dan pemahaman karyawan tentang program ESOP dapat menghasilkan program ESOP yang kurang efektif; (2) kurangnya pengetahuan karyawan atas risiko yang bakal terjadi pada program ESOP juga membuat program ESOP kurang efisien.

Manfaat ESOP dikelompokkan kepada lima hal, yaitu (Brigham, 2013): (1) dapat meningkatkan produktivitas karyawan, sehingga kinerja perusahaan akan naik, dan akan menambah kemakmuran bagi shareholders; (2) dapat menambah kekayaan karyawan karena terdapat transfer kekayaan dari share holders' kepada karyawan melalui kepemilikan sebagian saham; (3) ESOP membantu perusahaan dalam menjaga karyawannya dengan baik, yang mana hal ini sesuai dengan hasil penelitian Gilligan (2017) yaitu bahwa ESOP merupakan alat perusahaan untuk memelihara karyawannya karena ESOP menguntungkan karyawan, sehingga karyawan kerasan bekerja di perusahaan ; (4) adanya insentif perpajakan yaitu pendapatan atas bunga yang tidak dikenakan pajak, bagi lembaga keuangan yang memberikan loan kepada program ESOP yang diselenggarakan oleh perusahaan lain; deviden dari program ESOP juga deductible, serta pembayaran hutang ESOP juga deductible; (5) menghindarkan perusahaan dari penguasaan oleh perusahaan lain.

Prasetio (2013), menyatakan bahwa penerapan ESOP memungkinkan karyawan untuk memperoleh saham yang akan menguntungkan karyawan. Kepemilikan saham ini dapat dilakukan dengan caracara sebagai berikut: (1) stock grants - yaitu pemberian saham kepada karyawan kunci sebagai penghargaan dan untuk mempertahankan karyawan; (2) direct employee stock purchase plans - karyawan memiliki hak untuk membeli saham perusahaan, agar karyawan memiliki rasa memiliki sehingga kinerjanya meningkat; (3) stock option plan - karyawan memiliki hak untuk membeli saham pada periode tertentu saja; (4) Employee Stock Ownership Plans - karyawan berinvestasi dalam saham perusahaan, kemudian memperoleh return. Hal ini banyak dilakukan seperti pada program pension; (5) phantom stock and stock appreciation rights (SARS) - hibah yang diberikan perusahaan kepada karyawan untuk menerima kas sebesar kenaikan harga tertentu dari saham perusahaan.

Pendapat bahwa motivasi karyawan dapat ditingkatkan melalui penggunaan program ESOP, dikemukakan oleh Wahidahwati \& Budiman (2017), yang menyatakan bahwa ESOP memberi pengaruh positif terhadap kinerja perusahaan karena meningkatkan motivasi karyawan dan akan meningkatkan value perusahaan. Selanjutnya harga saham perusahaan akan naik sehingga karyawan lebih 
sejahtera dan keberlanjutan perusahaan tercapai. ESOP dapat dilakukan melalui dua pendekatan berikut ini: (1) Pendekatan Kompensasi Ekuitas - menganggap bahwa perusahaan dapat memaksimalkan kinerjanya dengan memberikan insentif keuangan yang tepat bagi orang yang tepat di perusahaan, sehingga perusahaan menambahkan kepentingan ekuitas pada unsur tradisional gaji dan bonus kas agar insentif keuangan lebih efektif; (2) Broad-based Ownership-memberikan insentif keuangan kepada karyawannya karena akan memperoleh keuntungan tambahan dari karyawan yang juga merupakan pemilik perusahaan.

Investor seringkali lebih tertarik berinvetasi pada perusahaan yang telah menerapkan ESOP. Seperti hasil riset Anggrawan (2018), yang menyimpulkan bahwa ESOP telah menjadi salah satu bentuk Corporate Social Responsibility (CSR) perusahaan pada bidang kesejahteraan karyawan, dan hal ini sering menjadi daya tarik investor untuk berinvestasi. Walaupun terdapat pula hasil penelitian yang berbeda, Hartono (2014) menyimpulkan bahwa berdasarkan Rasio profitabilitas, rasio aktivitas, rasio solvabilitas dan rasio lain ternyata tidak terdapat perbedaan yang signifikan atas kinerja perusahaan sebelum dan sesudah menerapkan ESOP.

Laba bersih perusahaan merupakan unsur yang terdapat dalam Laporan Laba Rugi (William, et al, 2015). Laporan Laba Rugi menggambarkan Laba atau Rugi perusahaan dalam kegiatannya menghasilkan suatu barang atau jasa dan proses penjualannya pada suatu periode tertentu. Laporan ini berisi informasi tentang pendapatan, biaya pokok penjualan, biaya administrasi, penghasilan lain-lain, dan beban lain-lain. Bila pendapatan perusahaan lebih besar dari biaya-biaya yang mengiringinya maka akan dihasilkan Laba dan bila sebaliknya maka akan dihasilkan Rugi.

Perusahaan yang menghasilkan laba yang tinggi akan memberikan kompensasi kepada karyawan dengan tinggi pula. Serta harga saham perusahaan tersebut akan meningkat (Brigham, 2013), kesejahteraan karyawan akan meningkat pula, selain itu keberlanjutan operasi perusahaan di masa-masa yang akan datang juga dapat dicapai (Susilawaty, 2017 seperti dikutip oleh Putra, 2018).

\section{METODE}

Metode yang digunakan pada penelitian ini, adalah metode studi deskriptif. Tujuannya untuk mendapatkan data yang valid sehingga dapat ditemukan, dibuktikan, dan dikembangkan suatu pengetahuan untuk memahami, memecahkan dan mengantisipasi masalah. Prosesnya dimulai dari pengolahan data, analisis, interpretasi melalui pembahasan yang teratur dan sistematis dan dengan membuat kesimpulan yang sesuai.

Metode studi Deskriptif, memenuhi kriteria umum dan khusus, yang mana: kriteria umum - yaitu terdapat nilai ilmiah pada masalah yang dirumuskan, tujuan penelitian dinyatakan secara khusus, data nya merupakan fakta, serta ada validitas pada standar yang digunakan sebagai perbandingan. Sedangkan kriteria khusus yaitu data yang dinyatakan dalam nilai, fakta serta prinsip dalam membahas masalah status, sifat penelitian ex post facto yang berarti tidak terdapat control terhadap variabel dan peneliti tidak melakukan manipulasi terhadap variabel.

Objek yang diteliti adalah PT. Bandung merupakan sebuah perusahaan Lembaga Keuangan dengan karyawan sebanyak 1.509 orang (pada saat penelitian dilakukan yaitu Tahun 2017). ESOP yang dilakukan ditujukan demi kepentingan karyawan serta kebaikan perusahaan di masa datang, karena diharapkan dapat menumbuhkan sense of belonging karyawan, sehingga motivasi karyawan dalam bekerja meningkat dan produktivitasnya pun meningkat. Harapan lainnya, dengan mengimplementasikan program ESOP, perusahaan dapat memperoleh segala manfaat ESOP yang akan menguntungkan perusahaan (Gambar 1).

Langkah-langkah yang dilakukan dalam penelitian ini, dirangkum sebagai berikut: (1) menentukan topik dan judul yang diteliti, yaitu Bagaimanakah pelaksanaan program ESOP di PT. Bandung dapat meningkatkan komitmen karyawan, yang diukur melalui proksi Laba khususnya yang terdapat di PT. Bandung; (2) menentukan objek dan variable yang diteliti, dalam hal ini Objek penelitian adalah PT. Bandung dengan variabel yang diteliti (a) penerapan ESOP dan (b) Laba perusahaan; (3) studi pustaka yaitu melakukan pencarian literatur yang mendukung teori yang digunakan dalam penelitian; (4) Teknik pengumpulan data dilakukan dengan cara: wawancara dengan para Komisaris dan Direksi PT. Bandung, serta mengumpulkan data sekunder dari publikasi-publikasi yang berkaitan dengan objek penelitian serta mencari jurnal atas penelitian sebelumnya yang telah dilakukan yang terkait dengan penelitian ini; (5) Teknik analisis data yang dipakai adalah dengan cara membandingkan informasi hasil penelitian yang diperoleh dengan teori yang terkait serta dengan hasil penelitian-penelitian sebelumnya; (6) melakukan analisis pembahasan berdasarkan langkah ke (5) dan membuat kesimpulan pada kasus yang diteliti.

\section{HASIL}

Goal manajemen yang paling penting dalam mengelola suatu perusahaan adalah meningkatkan Nilai/ value perusahaan, karena hal ini akan mempengaruhi tingkat kemakmuran pemilik, serta mempengaruhi kinerja perusahaan (Brigham: 2013). Perusahaan yang kinerjanya semakin baik, akan memperoleh emage yang semakin baik juga serta menumbuhkan kepercayaan masyarakat. Seperti pada hasil penelitian Kalra dan Bagga (2017), bahwa terdapat hubungan timbal balik yang positif antara penerapan ESOP 
dalam peningkatan kinerja perusahaan besar. Riaz et al. (2017) meneliti hubungan ini pada perusahaan kecil (small business) di Karachi, dan membuat kesimpulan bahwa terdapat korelasi yang signifikan secara statistik peningkatan kinerja perusahaan kecil dengan penerapan ESOP.

Peningkatan kinerja perusahaan memerlukan peningkatan prestasi kerja perusahaan; diantaranya memerlukan tambahan Modal, tambahan efisiensi operasi serta tambahan produktivitas karyawan yang dimungkinkan oleh adanya kenaikan komitmen dari karyawan. Seperti hasil penelitian Hutnaleontina \& Suputra (2013), menyatakan bahwa peningkatan komitmen dan semangat kerja karyawan dapat dicapai bila rasa memiliki karyawan terhadap perusahaan juga meningkat, kepemilikan karyawan dapat terwujud salah satunya melalui program ESOP.

Karyawan yang telah mengeksekusi hak opsinya dan membeli saham perusahaan, akan merasa turut serta memiliki perusahaan, sehingga akan mengupayakan produktivitas kerja yang lebih baik, untuk meningkatkan Nilai perusahaan. Dalam hal ini diperlukan juga koordinasi dan pengarahan dari manajemen untuk melaksanakan serangkaian tindakan yang dilakukan bersama-sama, yang seluruhnya memiliki satu tujuan yang sama yaitu meningkatkan nilai perusahaan. Seperti pada penelitian Kato et al. (2016) - bahwa ESOP yang diterapkan oleh perusahaan telah terbukti meningkatkan produktivitas, profitabilitas, dan gaji karyawan sehingga kinerja perusahaan meningkat pula.

Peningkatan nilai perusahaan akan berdampak semakin besarnya kontribusi perusahaan kepada stake holders nya baik, para pemegang saham, manajemen perusahaan, karyawan, pemasok, pemerintah, kreditur, dan masyarakat. Para stake holders/warga perusahaan tersebut dapat memperoleh keuntungan baik melalui kenaikan gaji nya, kenaikan dividen ataupun kenaikan capital gain. Sehingga khususnya para karyawan dapat meningkatkan taraf hidupnya dan tingkat kesejahteraan nya. Walaupun bukan kesejahteraan seluruh warga masyarakat Bandung yang dibantu oleh perusahaan namun dengan kontribusi yang semakin lama semakin besar terhadap kesejahteraan warga nya maka peusahaan secara tidak langsung telah turut membantu Kota Bandung dalam mencapai program walikota nya yaitu meningkatkan kesejahteraan dan kebahagiaan warga Bandung. Di bawah ini disampaikan skema Proses Peningkatan Nilai Perusahaan berbasiskan program ESOP.

Hasil observasi dan wawancara dengan para dewan komisaris, menunjukkan bahwa implementasi bentuk kepemilikan saham oleh karyawan di PT. Bandung, adalah program yang dinamakan Employee Stock Ownership Program (ESOP) yaitu jenis kepemilikan saham oleh karyawan untuk mensejahterakannya. Penerapan program ESOP pada PT Bandung, melalui pembentukan badan pengelola dana dalam bentuk saham yang dikelola untuk kepentingan karyawan yaitu program kepemilikan saham oleh karyawan.

Para karyawan PT. Bandung, diakomodir untuk memiliki sebagaian saham perusahaan. Program ini diperuntukkan bagi tingkat eksekutif atau para manajer dari level bawah, menengah dan atas. Tujuan penyelenggaraan program ini diperusahaan adalah untuk memberikan penghargaan kepada karyawan, dampak program ini diharapkan diterima perusahaan secara jangka panjang. Perusahaan telah mensosialisasikan manfaat dan risiko tentang program ESOP ini kepada para karyawannya, sehingga karyawan memperoleh informasi yang cukup dan dapat membuat keputusan melakukan pembelian saham perusahaan dengan jumlah yang lebih tepat.

Saham yang didistribusikan ke dalam program ESOP pada PT. Bandung ini merupakan common stock, yang mana para pemegang saham secara bertahap merelakan sebagian sahamnya untuk dimiliki oleh para karyawan. Karyawan dapat memperoleh sahamnya sejumlah proporsional dengan besarnya gaji/ salary bulanannya serta periode lamanya kerja. Namun, saham karyawan tersebut akan diberikan ketika karyawan pensiun, karena tujuannya adalah agar terjadi penambahan kekayaan karyawan saat yang bersangkutan pensiun, terutama karena karyawan akan memperoleh capital gain yang cukup besar akibat kenaikan harga pasar saham saat harga awal saham diberikan kepada karyawan sampai saat pensiun. Sedangkan manfaat untuk perusahaan adalah untuk tax benefit. Hal ini sama seperti kesimpulan penelitian Burke (2015) - yaitu ESOP selain menguntungkan karyawan juga menguntungkan perusahaan terutama dari sudut pandang benefit atas provisi deffered tax.

Karyawan menerima program ini dengan besar hati karena mereka menjadi merasa memiliki perusahaan. Mereka terdorong untuk bekerja lebih baik untuk perusahaan dengan motivasi untuk meningkatkan kinerja perusahaan, hal ini sesuai dengan hasil penelitian Chegg (2018) - bahwa motivasi karyawan bertambah karena perusahaan menerapkan ESOP. Komitmen yang diberikan karyawan kepada perusahaan sangat tinggi, karena karyawan berharap bila kinerja perusahaan makin baik maka harga pasar saham perusahaan makin tinggi dan return yang mereka terima baik dari deviden maupun dari capital gain akan semakin besar pula. Selain itu para karyawan semakin sedikit yang berpindah ke perusahaan lain, karena mengetahui bahwa bekerja di perusahaan lebih menguntungkan. Hal ini nampak dari makin kecilnya angka turn over karyawan. Di bawah ini disajikan skema proses implementasi program ESOP pada PT. Bandung.

\section{PEMBAHASAN}

PT. Bandung membuat program ESOP dengan menerbitkan 600.000 lembar Saham biasa. Setiap 
karyawan pada level manager akan menerima ownership interest melalui kepemilikan saham proporsional dengan besarnya gaji dan lamanya bekerja di perusahaan.

Perusahaan menyetorkan dana ke program ESOP nya sebesar IDR 600 jt yang dianggap sebagai pinjaman dari perusahaan. Neraca PT. Bandung sebelum adanya program ESOP dapat ditunjukkan seperti pada Tabel 1.

Tabel 1. Neraca PT. Bandung (sebelum pendirian ESOP)

\begin{tabular}{lrlr}
\hline \multicolumn{2}{c}{ Assets (dalam Juta) } & Liabilities \& Capital (dalam Juta) \\
\hline Cash & IDR 1.000 & Hutang & IDR 2.000 \\
Aset Lainnya & 6.587 & Ekuitas & IDR 5.587 \\
Total Aset & IDR 7.587 & Total Liabilitas \& Ekuitas & IDR 7.587 \\
\hline
\end{tabular}

Sumber: Data perusahaan - diolah kembali

Pada Tabel 1 nampak Total asset perusahaan sebesar Rp. 7.587 juta yang diimbangi dengan jumlah hutang sebesar Rp 2.000 juta dan ekuitas sebesar Rp. 5.587 juta; kondisi keuangan PT. Bandung ini mencerminkan sebelum dibentuknya program ESOP.

Sedangkan Neraca PT. Bandung sesudah mengimplementasikan program ESOP, nampak seperti pada Tabel 2.

Tabel 2. Neraca PT. Bandung (setelah pendirian ESOP)

\begin{tabular}{|c|c|c|c|}
\hline \multicolumn{2}{|c|}{ Assets (dalam Juta) } & \multicolumn{2}{|c|}{ Liabilities \& Capital (dalam Juta) } \\
\hline Cash & IDR 400 & Hutang & IDR 2.000 \\
\hline & & Ekuitas & IDR 5.587 \\
\hline Aset Lainnya & 6.587 & Treasury Stock & IDR 600 \\
\hline Total Aset & IDR 6.987 & Total Liabilitas \& Ekuitas & IDR 6.987 \\
\hline
\end{tabular}

Sumber: Data perusahaan - diolah kembali

Setelah adanya implementasi program ESOP, nampak nilai asset PT. Bandung terjadi penurunan seperti terlihat pada Tabel 2, namun dari sisi maknanya terlihat bahwa perusahaan telah menjamin terimplementasinya program ESOP perusahaan dengan sangat memadai, sehingga perusahaan akan memperoleh manfaat perpajakan yaitu: insentif perpajakan bahwa pendapatan atas bunga dari $\mathrm{Rp} 600$ juta yang disetorkan tidak dikenakan pajak; deviden dari program ESOP juga deductible, serta pembayaran hutang ESOP juga deductible.

Pada program ESOP terdapat Neraca awal, seperti pada Tabel 3.

Tabel 3. Neraca Awal program ESOP

\begin{tabular}{|c|c|c|c|}
\hline \multicolumn{2}{|c|}{ Assets (dalam Juta) } & \multicolumn{2}{|c|}{ Liabilities \& Capital (dalam Juta) } \\
\hline PT. Bandung, & IDR 600 & Hutang & IDR 600 \\
\hline Stock & & Ekuitas & IDR 0 \\
\hline Total Aset & IDR 600 & Total Liabilitas \& Ekuitas & IDR 600 \\
\hline
\end{tabular}

Sumber: Data perusahaan - diolah kembali
Pada Tabel 3 terlihat bahwa Total asset awal pada program ESOP adalah sebesar Rp. 600 Juta. Perlu diinformasikan bahwa saat ini yaitu per 23 Mei 2017, harga pasar saham/lembar saham PT. Bandung sebesar Rp. 1.910,-

Dampak implementasi ESOP akan diukur menggunakan proksi Laba perusahaan, sebab karyawan yang telah memperoleh kepemilikan di dalam perusahaan, akan memberikan hasil kerja yang lebih tinggi dan hal ini tercermin dalam Laba yang dicapai perusahaan. Hasil penelitian atas penerapan program ESOP beberapa bulan sebelum berakhirnya periode tahun 2016, ternyata dapat dilihat tercapainya peningkatan Laba setiap Bulan terutama pada periode Januari sampai April 2017. Di bawah ini disampaikan data tentang laba perusahaan setelah tahun sebelumnya memberlakukan program ESOP.

Tabel 4. Data Laba PT. Bandung Periode Januari - April 2017

\begin{tabular}{lcrrrr}
\hline & $\begin{array}{c}\text { Laba } \\
\text { (dalam } \\
\text { M) }\end{array}$ & $\begin{array}{c}\text { presentase } \\
\text { terhadap } \\
\text { bulan lalu }\end{array}$ & $\begin{array}{c}\text { total laba } \\
\text { kumulatif }\end{array}$ & $\begin{array}{c}\text { Total } \\
\text { Assets } \\
\text { (Milyar) }\end{array}$ & $\begin{array}{c}\text { ROA } \\
(\%)\end{array}$ \\
\hline $\begin{array}{l}\text { Januari } \\
2017\end{array}$ & $1,006 \mathrm{M}$ & - & - & 7,587 & 0.01 \\
$\begin{array}{l}\text { Februari } \\
2017\end{array}$ & 2,310 & $130 \%$ & 3,316 & 7,585 & 0,03 \\
Maret & 5,263 & $180 \%$ & 8,579 & 7,700 & 0,06 \\
2017 & & & & & \\
April & 1,729 & $-67 \%$ & 10,308 & 7,709 & 0,02 \\
2017 & & & & & \\
Total & & & 10,308 & 7,645 & 0,14 \\
\hline
\end{tabular}

Sumber: Data perusahaan diolah

Tabel 4 menunjukkan terdapat pencapaian laba dalam perusahaan yang semakin meningkat dari bulan ke bulan selama Januari sampai April 2017 ini. artinya bila ditarik rata-rata untuk 12 bulan penuh selama tahun 2017 ini, maka akan diperoleh perkiraan Laba perusahaan berkisar secara rata-rata $\mathrm{Rp} 30,924 \mathrm{M}$; dibandingkan dengan capaian laba tahun 2016 yaitu sebesar Rp $12 \mathrm{M}$ sehingga terdapat peningkatan laba sekitar 257,7\%. Hasil studi ini sesuai dengan hasil studi Walker (2018) yang menyatakan bahwa penerapan ESOP telah memungkinkan peningkatan insentif dan reward karena Laba perusahaan meningkat dengan tajam. Hal ini berarti kemampuan financial perusahaan semakin baik, sehingga operasinya dapat diperluas, yang akan menghasilkan laba yang lebih tinggi lagi. Pada gilirannya nilai perusahaan meningkat, harga saham perusahaan naik dan dapat memberikan kompensasi kepada seluruh stake holdernya lebih tinggi pula. Tentunya para stake holders nya dapat meningkatkan kesejahteraan dan kebahagiannya. Hasil penelitian ini selaras dengan penelitian Hutnaleontina \& Suputra 
(2013) yang menyimpulkan bahwa semakin tinggi jumlah saham yang dimiliki karyawan, semakin tinggi semangat dan motivasi karyawan untuk meningkatkan kinerjanya, sehingga kinerja perusahaan yang diproksi dengan Return on Assets (ROA) makin baik dan harga sahamnya meningkat.

Berdasarkan hasil wawancara dengan dewan komisaris, diperoleh informasi bahwa perusahaan juga memperoleh keuntungan perpajakan yaitu pendapatan bunga atas pinjaman yang diberikan untuk dana ESOP tidak dikenakan pajak, serta dividen ESOP sifatnya deductible. Hal ini sesuai dengan Burke (2015) dan Brigham (2013) yaitu bahwa penerapan ESOP menghasilkan benefit perpajakan.

Hasil penelitian ini berimplikasi bahwa perusahaan yang telah menerapkan ESOP, akan memperoleh kenaikan laba yang memadai karena para karyawannya memberikan prestasi kerja yang semakin meningkat. Karyawan diberi penghargaan karena dapat menjadi pemilik sebagian perusahaan, sehingga karyawan akan mempertahankan kerja di perusahaan dalam jangka waktu yang panjang. Bagi perusahaan yang telah gopublic penting untuk menerapkan ESOP seperti ini, karena berdampak sangat positif yaitu meningkatkan kinerja perusahaan serta tercapainya keberlanjutan usahanya (Gambar 2).

Implikasi lainnya untuk pengembangan ilmu, diantaranya adalah bahwa penelitian ini dapat dilanjutkan dengan mengukur sampai sejauh mana peningkatan kesejahteraan dan kebahagiaan warga perusahaan sebagai dampak diterapkannya program ESOP, sehingga menjadi lebih terukur dampak atas implementasi ESOP tersebut.

\section{KESIMPULAN}

Jenis kepemilikan saham oleh karyawan yang diterapkan di PT Bandung, adalah pembentukan badan pengelola dana dalam bentuk saham yang dikelola untuk kepentingan karyawan yaitu program kepemilikan saham oleh karyawan yang disebut dengan program Employee Stock Ownership Plans (ESOP).

Pembentukan program ESOP di PT Bandung, dimulai dengan pengalihan sebagaian saham biasa perusahaan sebesar Rp. 600 Juta yang setara dengan 600.000 lembar saham. Karyawan setingkat manajer dapat membeli saham dengan harga tertentu sebesar proporsi gaji dan lamanya bekerja. Saham akan diberikan kepada karyawan bersangkutan setelah pensiun.

Hasil penelitian juga telah membuktikan terdapat dampak yang nyata atas implementasi program ESOP pada PT Bandung, yaitu telah meningkatkan komitmen dan motivasi karyawan. Ditunjukkan oleh jumlah laba yang dihasilkan yang meningkat terus dan bila dibandingkan dengan tahun yang lalu 2016, maka secara rata-rata laba meningkat $257,7 \%$. Hal ini berdampak terhadap peningkatan nilai perusahaan serta kompensasi yang diberikan yang lebih tinggi, sehingga warga perusahaan akan semakin sejahtera dan bahagia, dan secara jangka panjang keberlanjutan operasi perusahaan dapat dicapai.

\section{DAFTAR PUSTAKA}

Anggrawan, Deviany Siswani. 2018. ESOP Salah satu bentuk CSR. Jurnal: publication.petra.ac.id. Diunduh 15.11.2018 pk. 14.00.

Brigham, Eugene F., Phillip R.D. 2013. Intermediate Financial Management. 11th edition; United Stated: South Western, Cengage Learning.

Burke, Megan M. 2015. Benefits of an Employee Stock Ownership Plan in Succession Planning. Journal of Accountancy Oct 2nd 2015. (https:// www.journalofaccountancy.com/issues/2015/oct. esop-benefit-in- succession-planning.html.I)

Chegg. 2018. Study Employee Stock Ownership Plans (ESOPS) Increase Company's value. Textbook Solution Expert QA. (2003) - 2018

Gilligan, Wendy. 2017. The Employee Stock Ownership Plan Basics You Need to Know. Employee Benefits Law Group: Attorneys \& Consultants. June, 1st 2017.

Harian Kompas, berbagai terbitan 2017. Penerbit: Jakarta.

Hartono, Agus. 2014. Pengaruh Employee Stock Ownership Program terhadap Kinerja Perusahaan. Jurnal MODUS Vo. 26 (1): pp. 85 - 91, 2014.

Herdinata, Christian. 2012. Reaksi Pasar terhadap Pengumuman Employee Stock Ownership Program. Jurnal Keuangan dan Perbankan Vol 16, No. 1. Jan 2012. Pp. 77-85. Terakreditasi SK No. 64a/DIKTI/ Kep/2010. http://jurkubang.wordpress.Com.

Hutnaleontina, Putu Nuniek \& Suputra, I Dewa Gede Dharma. 2016. Pengaruh Penerapan Employee Stock Option Plan pada Nilai Perusahaan dengan Kinerja Keuangan sebagai variable Intervening. Publikasi pada E-Journal Ekonomi \& Bisnis Universitas Udayana.

Ikatan Akuntan Indonesia. 2004. Pernyataan Standar Akuntansi Keuangan (PSAK) No. 53 - tentang Pembayaran kepada Karyawan Berbasis Saham. Jakarta.

Kalra, Neha and Bagga Rajesh. 2017. A Review of Employee Stock Option Plan: Panacea or Pandora's Box for Firm Performance. International Journal of Management Exellence Vol 10 No. 1 December 2017.

Kato, Takao; Hideaki Miyajima; Hidea Owen. 2016. Does Employee Stock Ownership Work? Evidance from Publicly Traded Firm in Japan. Paper Presentation at the Sole Meeting. https://www. sole-jole-org/16485.pdf.

Prasetio, Bimo. 2013. www.bimoprasetio.com/peluang. karyawan.menjadi.pemegang. saham.dalam. perusahaan. diunduh $15.11 .2018 \mathrm{pk} .15 .00$ 
Putra, Firdaus. 2018. Keadilan, Demokrasi, dan Saham untuk Karyawan Sumber: Kompas.com. 02/05/2018. Diunduh pada 15.11.2018 pk. 13.30

Riaz, Fayyaz; Fiza Abdul Razzaq; Ahsan Wagar. 2017. Effect of Employee Stock Ownership Plans (ESOPs) on The Performance of Small business in Karachi. MPRA (Munich Personal RePEs Archive) - Paper No. 84322. August 10th 2017.

Ripperger, Jerry L. 2018. How Employee Ownership Benefits Executives, Companies, and Employees American Management Association (AMA) 877: 566-9441(https://www.amanet.org/articles/ how-employee-ownership-benefits-executivescompanies-and-employees.aspx)

Tarigan, Andrew J., Bismar Nasution, Keizerina Devi. 2013. Aspek Yuridis Kepemilikan Saham bagi Karyawan pada Perseroan Terbuka (PT. Tbk). Jurnal Hukum Ekonomi Vol. 11 No. 2 Juni 2013.

Wahidahwati, dan Arip Budiman. 2017. Pengaruh harga Eksekusi \& ESOP terhadap Kinerja Perusahaan yang dimoderasi oleh Kepemilikan manajerial. STIESIA Surabaya. Https://core.ac.uk/jurnal. (2017). Diunduh 15.11.2018 pk. 14.30.

Walker, Jackson. 2018. Stock Option Plan example. UTSA Colledge of Business. https://www. business. utsa-edu/wp-content/upload/2018/03/12083345-2stock- option-plan.pdf.

Williams JR., SF Haka, MS Bettner and JV Carcello. 2015. Financial and Managerial Accounting: The Basis for Business Decision. 16th edition; Mc GrawHill Education New York. ISBN: 9780071220125. www.portal.bandung.go.id/posts/2017/05/16/ X9D2. Diunduh 18/05/2017 pk. 10.56

Zhu, Zhibiao; James Hoffmire; John Hoffmire; Fusheng Wang. 2013. Employee Stock Ownership Plans and Their Effect on Productivity - The Case of Huawei. International Journal of Business and Management Invation. ISSN (on line): 2319-8028; ISSN (Print): 2319-801X. www.ijbmi.org Vol 2 Issue 8/ August 2013/pp. 17-22.

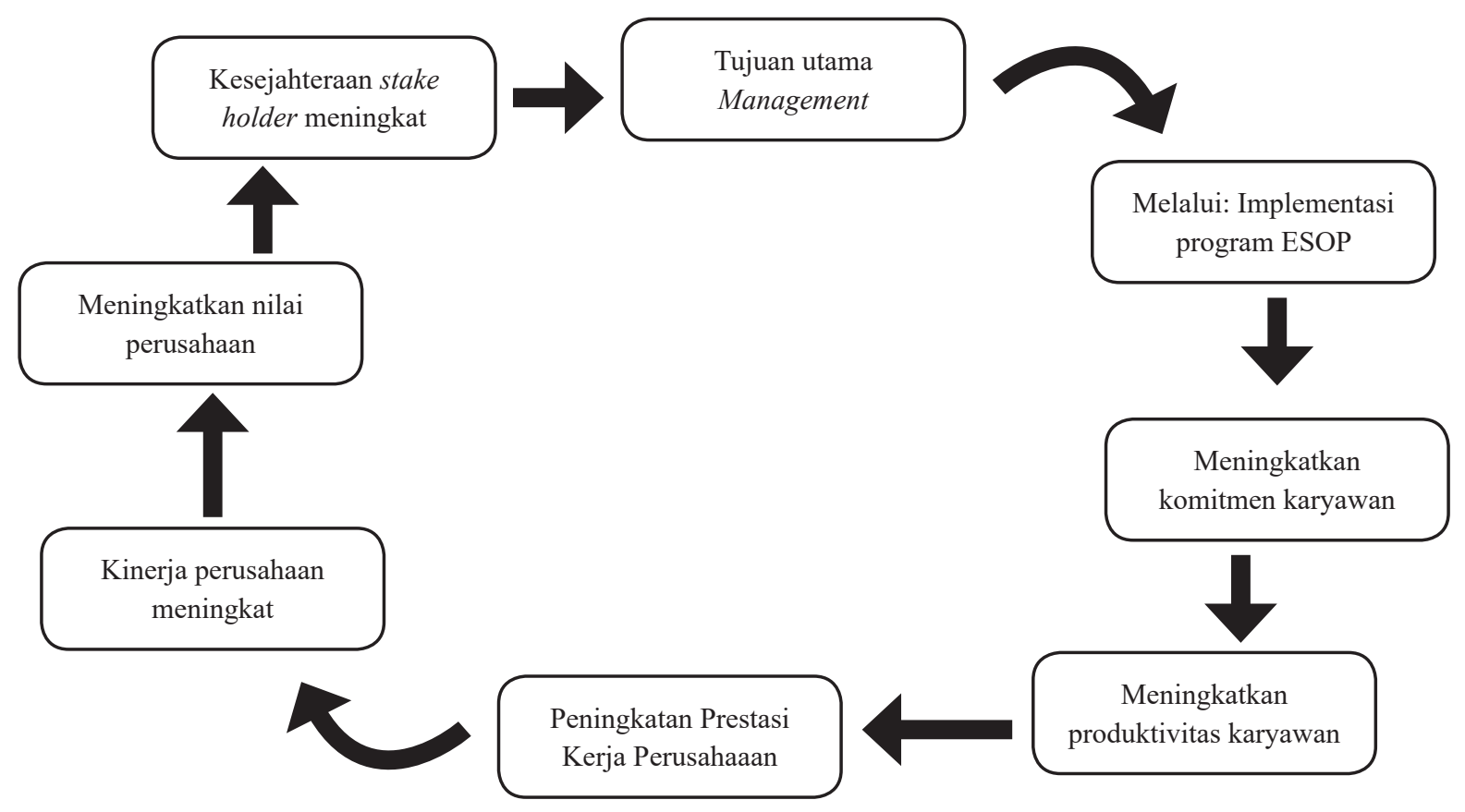

Gambar 1. Proses Peningkatan Nilai Perusahaan melalui ESOP 


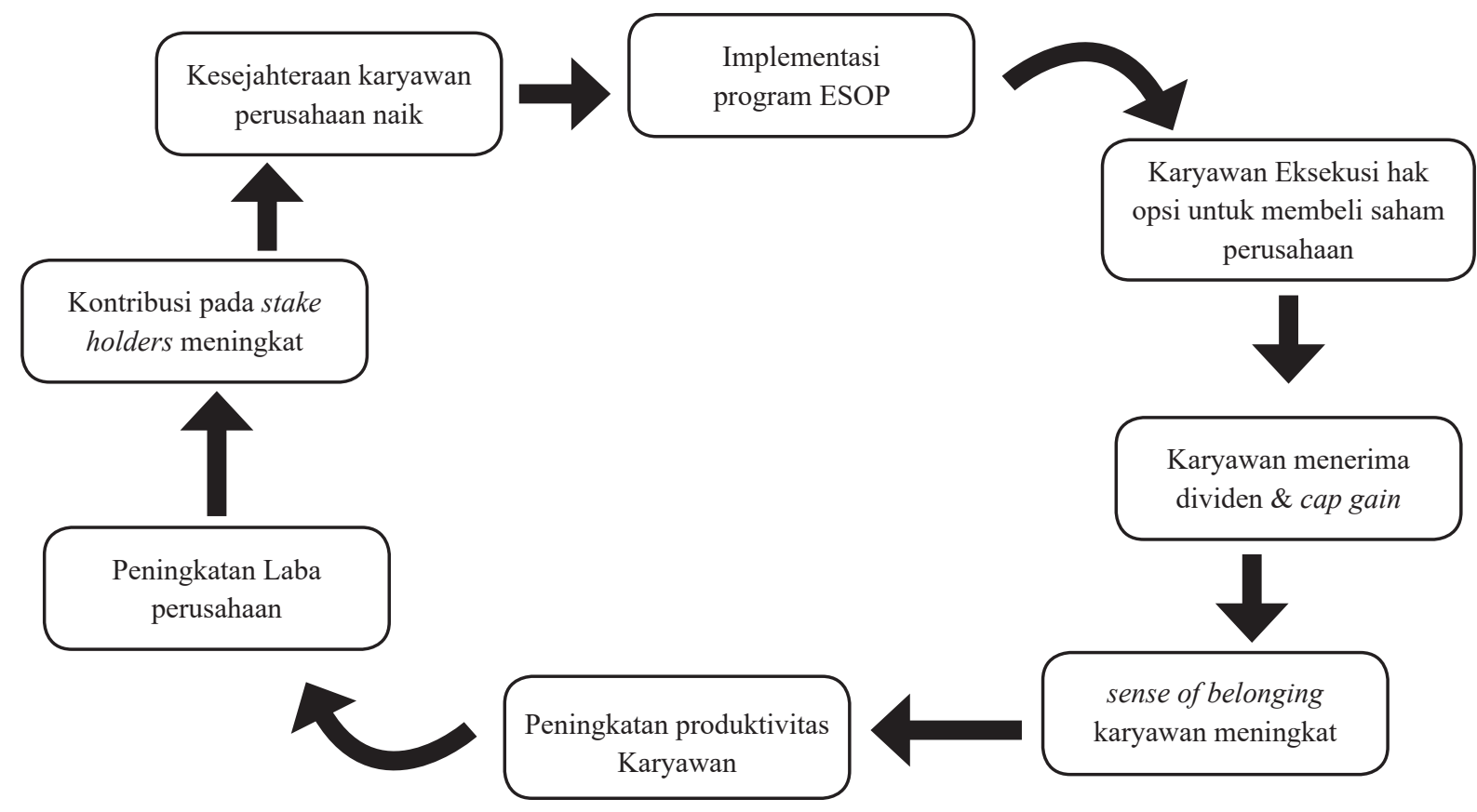

Gambar 2. Proses Implementasi ESOP di PT. Bandung 